\title{
A Study on Achievement Motivation of Adolescent Students of Different Academic Streams
}

\author{
Pretty Rani* and R. Geetha Reddy
}

Department of Home science extension and communication Management, Hyderabad, Professor Jayashankar Telangana State Agricultural University, Telangana, India

*Corresponding author

\section{A B S T R A C T}

\section{Ke yw ords \\ Adolescent, Achievement, Motivation, Achievement Motivation \\ Article Info \\ Accepted: 04 January 2018 Available Online: 10 February 2019}

Achievement motivation is prerequisite for achievement, to succeed and to perform well in relation to a standard of excellence. The present study was carried out with the objectives to examine the gender related differences and differences across academic majors on achievement motivation among adolescent students. It was measured by a scale developed by Norton (2006), which contained 22 items. The scale was slightly modified in accordance to the present research. The study was carried on 80 adolescent undergraduate students from Hyderabad district, 40 males and 40 females (ages 13-20 years) selected by purposive sampling method. Frequencies, percentages, means, standard deviations and independent t- test were used to analyze the collected data. Significant difference was found between the achievement motivation of sciences and arts stream students and achievement motivation among male and female college students.

\section{Introduction}

Adolescence is a time of growing, learning, adventuring, scoring and dreaming. It is a time of anxieties and problems. The term adolescence comes from Latin word "adolescere" meaning to grow into maturity. It is the period where individuals find their own abilities based on their interests. It is the period of potential stress as they experience new feelings and emotions. They face tremendous pressure and greater demands and expectation from various agents. Adolescents' perception activates the self-system providing information regarding past experiences, thoughts, behavior and environment. The selfsystem then forms conceptualizations of the adolescent's abilities. These perceptions become the motivational drive that accompanies the action.

Motivation is the driving force behind all the actions of an individual. The individual's needs and desires have a strong effect on the route of their behavior. Motivation is the internal condition that stimulates, direct and maintains behavior. There is a strong relationship between learning and motivation. According to Abraham Maslow when the need for love and belongingness are met, 
individual can then focus on higher level needs of intellectual achievement. At this stage urge to learn increases (Woolfolk, 2004). Absence of motivation is anobstacle in learning and a relevant cause in the decline of education standards.

To study the demographic profile of adolescent students

To know the level of Achievement motivation among the adolescent college students

To perceive the difference between the gender and the achievement motivation of the respondents

\section{Materials and Methods}

Based upon the nature of the research problem and objectives of the present study, exploratory research design was opted for the study. The city Hyderabad was purposely selected for the present study. Nearby Government colleges was purposively selected because of the availability and easy accessibility of the respondents. In this study, samples comprising of 80 adolescents including 40 females and 40 males consented to participate under the age group of 13-20 years were randomly selected. Interview schedule was developed to study the general profile of the adolescents. Achievement motivation scale developed by Norton (2006), which contained 22 items was slightly modified for assessing the motivation levels of adolescent students enrolled in different academic stream. The scale consists of 22 statements. All statements are of positive manner. 5 marks to strongly agree, 4 marks to agree, 3 marks to undecided, 2 marks to disagree and 1 mark to strongly disagree responses were assigned. The sum of marks is obtained for the entire scale. The higher the score, more is the well-being. Frequencies, percentages, means, standard deviations and
Independent t- test were used to analyze the collected data.

\section{Results and Discussion}

The table 1 shows that $(42.50 \%$ and $40 \%)$ in the present study was in the age group between 18-20 years in science and arts streams respectively, followed by age group $16-18$ years (37.50 and 32.50 ). The age group 14-16 of years constituted to be $25 \%$ and $22.50 \%$ of the respondents in the present study for science and arts stream respectively.

With regard to family type, $82.50 \%$ and $67.50 \%$ belonged to nuclear family. As much as $32.50 \%$ in arts stream and $17.5 \%$ in science stream belonged to joint family group. It clearly indicated that there is major shift in the family pattern from joint to nuclear family in cities.

Monthly income was operationalized as amount of money or its equivalent, received during a period of time in exchange for labor or services, from sale of goods and property. Mangal et al., (2014) studied to update the scale to measure the socioeconomic status of the individual, for both rural and urban area. It takes into account the per capita income of the individual and the as recommended for all health studies due to the ease of application. Hence the scale was used in the present study classified the sample based on monthly income as upper class (Rs. 53570-above per month), upper middle class (Rs.2652053560), middle class (Rs.15700-26510) and lower middle class (RS.8120-15690). The same classification is followed in the study as it is found appropriate.

The table 2 depicts the achievement motivation levels in male and female students. Female sample in the present study comprised of 40 and male students also were 40 in strength. As much as $57 \%$ of female 
respondents in the present study had moderate levels of achievement motivation whereas in the male respondents $50 \%$ of them had moderate levels of achievement motivation. It should be noted that $45 \%$ of the male respondents in the study had low levels of achievement motivation and in females only $26 \%$ had low levels of achievement motivation. A good number of the female respondents in the study i.e.30\% had high motivation whereas in case of males only $12 \%$ had high motivation.

It might be due to increased desire in female students to achieve their goals which was not seen in earlier times and that's why male students from previous time had more of achievement motivations as compared to female students. This change was seen which may be due to changing society's concern about success, praise and confidence regarding adolescents.

The table 3 depicts the levels of achievement motivation of the male and female adolescents of different streams of academic education viz science and arts. It was interesting to note that $23 \%$ females of science academic stream had high motivation levels and $15 \%$ of females in arts stream had high achievement motivation. When compared to females of arts stream $20 \%$ had high levels of achievement motivation and males in the particular stream had $5 \%$ of high levels of academic achievement motivation. As much as $28 \%$ of the female students in science stream and $23 \%$ of arts stream had moderate levels of achievement motivation, on the other hand female studying in arts streams had $23 \%$ of achievement motivation and $18 \%$ of male students studying arts streams had moderate levels of achievement motivation. It should be note that $18 \%$ of males had low levels of achievement motivation studying science whereas $23 \%$ of the males studying arts stream had low levels of achievement motivation.
Pany (2014) studied achievement motivation of science male and science female college students. The mean scores of sciences male and science female college students was found to be 20.68 and 24.81 and the standard deviation as 3.82 and 4.31 respectively. The $\mathrm{t}$ ratio of above groups was 5.079 which is significant at 0.01 level of significance. Therefore, there is significant difference between arts male vs. arts female and science male vs. science female achievement motivation levels. The scores give clear indication that science college students are more motivated than arts college students.

An inference can be drawn from the above table 4 that there was a significant difference in the achievement motivation of male and female students. These indicates that female students have a more desire to achieve success and goals in their life which was not seen in earlier times where male students had more motivation to achieve compared to female students. The changes were seen which may be due to changing society's concern about success, praise and confidence in female adolescent students especially studying science stream.

Anitha and Jebaseelan (2018) found there is a significant difference between the gender and the overall achievement motivation score. Concerning the dimensions, there is high significant difference between the gender and the Academic motivation, importance of Grade and marks, meaningfulness of tasks, Attitude towards education and teacher, interpersonal relation and the gender (male or female). And girls are highly motivated than boys in academics.

Devakumar (2018) studied gender differences in achievement motivation and academic selfconcept of SSC board students. It was found that there was significant difference in achievement motivation scores where the girls scored higher than the boys. On the contrary, 
there was very minimal difference in the academic self-concept scores on the basis of gender.

The study is in line with Maheswari and Aruna (2016) found that there is significant difference between the genders of the respondents with regard to their achievement motivation. From the mean score analysis, it was revealed that female respondents perceived better achievement motivation than the male respondents.

An inference can be drawn from the above table 5 that there was a significant difference among the achievement motivation of students of science and arts stream. Thus, achievement motivation of science stream was higher than arts studying students.

The desire among science students might be due to their self-belief regarding their present and defined goals for their future life which became driving force for high motivation. The unlimited opportunity after completion of their degree might also be responsible for high achievement motivational levels.

Upadhyay and Tiwari (2009) evaluated the effect of academic majors on achievement motivation of the students. Results showed students of science faculty had significantly higher achievement motivation in comparison to Social Science, Humanities and Commerce faculty, but it does not significantly differ from the vocational courses.

Table.1 Distribution of adolescents related variables

\begin{tabular}{|c|c|c|c|c|c|}
\hline S.no & \multirow{2}{*}{$\begin{array}{l}\text { Respondent } \\
\text { profile }\end{array}$} & $\begin{array}{l}\text { Science } \\
\text { group }\end{array}$ & Stream & $\begin{array}{l}\text { Arts } \\
\text { grou }\end{array}$ & stream \\
\hline \multirow[t]{4}{*}{1.} & & $\mathrm{~F}$ & $\%$ & $\mathrm{~F}$ & $\%$ \\
\hline & $14-16$ years & 10 & 25.00 & 9 & 22.50 \\
\hline & $16-18$ years & 13 & 32.50 & 15 & 37.50 \\
\hline & $18-20$ years & 17 & 42.50 & 16 & 40.00 \\
\hline \multirow[t]{3}{*}{2.} & Family Type & & & & \\
\hline & Nuclear & 33 & 82.50 & 27 & 67.50 \\
\hline & Joint & 7 & 17.5 & 13 & 32.50 \\
\hline \multirow[t]{5}{*}{4.} & Income status & & & & \\
\hline & $\begin{array}{l}\text { Low income } \\
\text { group }\end{array}$ & 4 & 10.00 & 4 & 10.00 \\
\hline & $\begin{array}{l}\text { Middle income } \\
\text { group }\end{array}$ & 19 & 47.50 & 20 & 50.00 \\
\hline & $\begin{array}{l}\text { Upper middle } \\
\text { class }\end{array}$ & 14 & 35.00 & 14 & 35.00 \\
\hline & $\begin{array}{l}\text { High income } \\
\text { group }\end{array}$ & 3 & 7.5 & 2 & 5.00 \\
\hline
\end{tabular}


Table.2 Achievement motivation among male and female adolescents $\mathrm{N}=80$

\begin{tabular}{|l|l|l|l|l|l|l|l|}
\hline S.No & $\begin{array}{l}\text { Achievement } \\
\text { motivation } \\
\text { category) }\end{array}$ & \multicolumn{2}{|l|}{ Men } & \multicolumn{2}{|l|}{ Women } & \multicolumn{2}{l|}{ Total } \\
\cline { 3 - 8 } & & $\mathbf{N}$ & $\mathbf{\%}$ & $\mathbf{N}$ & $\mathbf{\%}$ & $\mathbf{N}$ & $\mathbf{\%}$ \\
\hline $\mathbf{1}$ & High (81-110) & 2 & 5 & 12 & 30 & 14 & 35 \\
\hline $\mathbf{2}$ & Moderate (52-81) & 20 & 50 & 25 & 63 & 45 & 57 \\
\hline $\mathbf{3}$ & Low (22-51) & 18 & 45 & 3 & 8 & 21 & 26 \\
\hline
\end{tabular}

Table.3 Achievement motivation among male and female adolescents in science and arts streams $\mathrm{N}=80$

\begin{tabular}{|c|c|c|c|c|c|c|c|c|c|c|c|c|}
\hline \multirow{2}{*}{ Category } & \multicolumn{4}{|c|}{ Science } & \multicolumn{2}{|c|}{ Total } & \multicolumn{4}{|c|}{ Arts } & \multicolumn{2}{|c|}{ Total } \\
\hline & M & $\%$ & $\mathrm{~F}$ & $\%$ & $\mathrm{~F}$ & $\%$ & M & $\%$ & $\mathrm{~F}$ & $\%$ & $\mathrm{~F}$ & $\%$ \\
\hline High & 6 & 15 & 9 & 23 & 15 & 38 & 2 & 5 & 8 & 20 & 10 & 25 \\
\hline Moderate & 7 & 18 & 11 & 28 & 18 & 45 & 9 & 23 & 9 & 23 & 18 & 45 \\
\hline Low & 7 & 18 & - & & 7 & 18 & 9 & 23 & 3 & 8 & 12 & 30 \\
\hline
\end{tabular}

Table.4 Achievement motivation differences of adolescent in male and female $\mathrm{N}=80$

\begin{tabular}{|l|l|l|l|l|}
\hline Category & Sample size & Mean & SD & T value \\
\hline Male & 40 & 128.73 & 2.5 & 16.39 \\
\hline Female & 40 & 141.02 & 4.17 & \\
\hline
\end{tabular}

* significant at $5 \%$ level $(\mathrm{p}<0.05)$

Table.5 Achievement motivation of adolescent in science group and arts group $\mathrm{N}=80$

\begin{tabular}{|l|l|l|l|l|}
\hline Category & Sample size & Mean & SD & T value \\
\hline Science & 40 & 149.68 & 3.53 & 14.32 \\
\hline Arts & 40 & 118.72 & 3.00 & \\
\hline
\end{tabular}

* significant at $5 \%$ level $(\mathrm{p}<0.05)$

In conclusion, achievement motivation is one of the critical psychological factors determining future academic and occupational success. Therefore, education and counselling should be completed with trainings focused on psychological skills useful and desirable in everyday life. It is very unfortunate that not all students are able to perform satisfactorily due to lack of motivation. Curricular and cocurricular activities with adequate counseling helps to develop achievement motivation and thereby their academic performance. It is clear that the girls have more desire to achieve than boys. In the modern era girls, no more restricted to the four walls of their homes. They have ample opportunities to 
perform and to display their skills and talents. Teachers must make it clear to students, about the types of goals they should set for themselves and should make the students focus on mastering skills and behavior change rather than memorizing material. Teachers need teaching strategies that reduce academic gender differences. They need to encourage all students to achieve to their potential and to provide them with emotional and academic support when needed. It is therefore suggested that an exposure to self-esteem enhancement programmes and enhancement in positive self-concept should be made to change students' perceptions of themselves leading to an improvement in learning outcomes. The parents as well as the education authorities should engage in programmes that can motivate the students to improve their academic performance.

\section{References}

Anita, P. and Jebaseelan, S.U. (2018). Study on Achievement Motivation among Adolescent Students in Colleges of Trichirappalli, Dt. Journal Of
Humanities And Social Science.25-31. Devkumar, M. (2018). Gender Differences in Achievement Motivation and Academic Self Concept of SSC Board Students. Online International Interdisciplinary Research Journal, \{Bi-Monthly\}, Volume-08. 101-112.

Maheswari K, K and Aruna, M. (2016). Gender difference and achievement motivation among adolescent school students. Journal of applied science. 2(1): 149-152.

Pany, S. (2014). Achievement Motivation of College Students in relation to their Gender, Stream and Locale. Online International Interdisciplinary Research Journal, $\quad$ Bi-Monthly $\}$, Volume-IV.360-367

http://www.wwnorton.com/college/psych/psy chsci/media/survey.htm

Upadhyay. S., and Tiwari. A. (2009). Achievement Motivation across Different Academic Majors. Indian Journal of Social Science Researches, 6(2), 128-132.

\section{How to cite this article:}

Pretty Rani and Geetha Reddy, R. 2019. A Study on Achievement Motivation of Adolescent Students of Different Academic Streams. Int.J.Curr.Microbiol.App.Sci. 8(02): 228-233. doi: https://doi.org/10.20546/ijcmas.2019.802.028 